Pirohova, K., Myкytchyk, O., Afanasiev, S., Omelchenko, O., Sydorchuk, T., Stepanova, I., \& Kosheleva, O. (2021). Dynamics of Body Type Indicators of Adult Women Under the Influence of Aqua Fitness. Teoriâ ta Metodika Fizičnogo Vihovannâ, 21(2), $129-135$.

\title{
DYNAMICS OF BODY TYPE INDICATORS OF ADULT WOMEN UNDER THE INFLUENCE OF AQUA FITNESS
}

\author{
Karyna Pirohova $^{1 \mathrm{ABCD}}$, Olha Myкytchyk ${ }^{1 \mathrm{ABCD}}$, Sergiy Afanasiev ${ }^{1 \mathrm{ABCD}}$, Olena Omelchenko ${ }^{1 \mathrm{ABCD}}$, \\ Tetiana Sydorchuk $^{1 \mathrm{ABCD}}$, Iryna Stepanova ${ }^{1 \mathrm{ABCD}}$, Olena Kosheleva ${ }^{1 \mathrm{ABCD}}$
}

${ }^{1}$ Prydniprovsk State Academy of Physical Culture and Sport

Authors' Contribution: A - Study design; B - Data collection; C - Statistical analysis; D - Manuscript Preparation; E - Funds Collection

Corresponding Author: Olha Мукуtchyk, E-mail: molga.0604@gmail.com

Accepted for Publication: May 18, 2021

Published: June 25, 2021

DOI: 10.17309/tmfv.2021.2.05

\begin{abstract}
The study purpose was to determine the effectiveness of a differentiated approach to aqua fitness classes with women of the first period of adulthood.

Materials and methods. 30 adult women, whose average age was 30.57 years, took part in the study. The study was conducted during 2019-2020. Anthropometric measurements included body length, body weight, chest, shoulder, calf, thigh, waist, buttocks and wrist circumferences. To determine the overweight we calculated the body mass index. Measurements were taken at the end of each mesocycle of wellness training. Statistical analysis covered determination of mean, standard deviation, reliability of the differences (Wilcoxon signed-rank test).

Results. The effectiveness of a differentiated approach to aqua fitness classes was proven by improvement of women's body type. By the end of the study, there were no women with obesity class II and underweight. The number of women with obesity class I decreased by 3.33\%. The number of women with normal body weight increased by $13.37 \%$.

Conclusions. The implementation of a differentiated approach to aqua fitness classes with adult women has significantly corrected their body proportions. This allows recommending a differentiated approach according to a body type to implement into aqua fitness classes.

Keywords: aqua fitness, body type, differentiated approach, correction of body proportions, wellness classes.
\end{abstract}

\section{Introduction}

The current rate of society development leads to a deterioration of the population health. In adulthood, involutionary processes begin to appear in systems, organs and tissues (Leiros-Rodriguez, Romo-Perez, Perez-Ribao, \& Garcia-Soidan, 2019). This reduces motor activity and affects the physique (Dorofeeva, Yarimbash, \& Zavatska, 2018; Prylutska et al., 2019). Deviation of body components from optimal values negatively affects the physical and emotional state (Tomilina, 2016), and overweight exacerbates comorbidities (Anders, Bedorta, \& Brennan, 1992; Goncharova et al., 2020).

The most popular type of wellness classes that allows women to improve their body type is aqua fitness (Rýzková, Labudov, Grznár, \& Šmída, 2018). Aqua fitness affect the functional state of the body, the level of psycho-emotional state. They are a major factor in slowing down the aging process, maintaining good health and increasing physical

(C) Pirohova, K., Мукуtchyk, O., Afanasiev, S., Omelchenko, O., Sydorchuk, T., Stepanova, I., Kosheleva, O., 2021. activity (Shalaeva, Sazonova, \& Krokhina, 2018; Andrieieva et al., 2019; Goncharova et al., 2020; Vysotskaya, Shutova, \& Golubnichy, 2020).

Scientists have been actively researching the problems of health-improving physical education with adults. The analysis and systematization of modern fitness programs on health physical culture with women of mature age were carried out in the studies of Martyniuk (2016), Tkachuk, Soverda, Stepaniuk, and Kozibroda (2019), Belyak, Hrybovska, Muzyka, Ivanochko, and Chekhovska (2018).

There are number of scientific studies that substantiate the criteria for differentiation in physical education process with different group of people. Among the criteria for differentiation, experts note the following: low adaptive capacity of the organism (Kanishcheva, 2011), genetic factors (Dargatz \& Röwekam, 2017; Krutsevich \& Marchenko, 2020), hereditary factors (Borovik, 2013), the rate of biological development (Sitovsky, 2008) and physique (Ryabchenko, 2011; Trotsenko \& Pivovarov, 2018).

Scientists from different countries (Leiros-Rodriguez et al., 2019; Andrieieva et al., 2019; Goncharova et al., 2020; Vy- 
sotskaya et al., 2020; Foulis et al., 2021) confirmed data about the expediency of using body type indicators as a criterion for the differentiation in the process of physical education. However, these works do not reveal the features of differentiated approaches to aqua fitness classes with women of the first period of adulthood with different body types.

The study purpose was to determine the dynamics of adult women's physique under the influence of aqua fitness classes using a differentiated approach to training depending on their body type.

\section{Materials and methods}

\section{Study participants}

The study involved 30 women of the first period of adulthood. Women were divided by body type into 3 subgroups of 10 people each. The first subgroup included 10 women of normosthenic body type with normal body weight. The second subgroup involved 3 women of asthenic body type ( 1 woman with dystrophy of II degree and 2 ones - with dystrophy of I degree) and 7 women of normosthenic type with body weight at the lower limit of normal. The third subgroup comprised 10 women of hypersthenic body type (7 women with obesity class I and 3 ones - with obesity class II). The average age of women was $30.57 \pm 3.63$ years. All study participants gave written consent to participate in the study.

\section{Study organization}

The study was conducted during 2019-2020 years in fitness-club Sport Life in Dnipropetrovsk region (Ukraine). A differentiated approach was introduced in aqua fitness classes with women of mature age. The aim is to increase the level of physical state due to a marked improvement of women 's morphological parameters according to a body type and improvement of the functional capabilities, the development of physical qualities. For women of asthenic type we proposed to tone muscle tissue and increase body size, for women of normosthenic type - to maintain the current level of body size, for women of hypertensive type - reduction of the comprehensive body size).

The whole health and training process was divided into three stages - preparatory, basic and supporting. The main stage was divided into mesocycles. Mesocycles contained loading and recovery microcycles. During the loading microcycles, the volume, intensity, nature of motor activity, starting positions and equipment were gradually varied, increased and became more complicated.

Wellness classes were conducted three times per week for 45 minutes. Classes were designed according to the complex type of lesson.

The duration of the preparatory part of class was $10 \mathrm{~min}$ utes Heart rate ranged from 100 to 120 beats per minute. The main task is to prepare the body, muscles and joints to perform the main load.

The content of the main part was aimed at correcting morphological parameters according to the body type of women. Duration - 25 minutes.

Classes for women of asthenic type were aimed at toning muscle tissue and increasing the overall size of the body, improving the functional capabilities and development of physical qualities. Cyclic, acyclic, strength and complex coor- dination exercises were used. The exercises were aimed at the simultaneous work of large muscle groups of the legs, torso and arms. During the first two months of training (the stage of achieving the physical shape), women performed exercises without equipment at an average and above the average pace. Rest pauses between series of exercises lasted 15 seconds. From the third month (the stage of maintaining the physical shape), women performed $70-80 \%$ of exercises with equipment (Noodles, Aqua-jogger, Aqua-dumbbell). Intensity of loads was average and above the average. Rest pauses between series of exercises lasted 10-15 seconds. Heart rate ranged from 120 to 130 beats per minute. The amplitude of performance varied from above to maximum and vice versa.

Women of normosthenic type were offered strength endurance, cyclic, acyclic and high-intensity coordination exercises. It was taken into account that women of this type of physique need to maintain the existing level of body size, functional state of the cardiovascular and respiratory systems. During the stage of achieving the physical shape, women performed exercises without equipment at above the average (heart rate was $120-130$ beats per minute) and high pace (heart rate was $130-160$ beats per minute). At the stage of maintaining the physical shape, $50 \%$ of exercises were performed with equipment with a high pace. Depending on the type of exercise, the rest between series was 5-10 seconds, the amplitude of performance varied from minimum to average, from average to maximum, from maximum to minimum.

Hypertensive type of women required weight loss and size parameters. They used cyclic aerobic exercises of strength endurance focus, acyclic exercises and exercises of complex-coordination focus with high and average intensity. During the stage of achieving the physical shape, women performed exercises without equipment with average pace (heart rate was 90-120 beats per minute). Rest between series was 15-20 seconds depending on the type of exercise. At the stage of maintaining the physical shape, exercises were performed at a higher than the average (heart rate was 120-130 beats per minute) and high (heart rate was $130-160$ beats per minute) rates. Aqua fitness exercises were varied: $30 \%$ - with equipment and $70 \%$ - without equipment. Depending on the type of exercise, the rest between series was $10-15$ seconds, the amplitude varied from minimum to average, from average to maximum, from maximum to minimum.

The final part of the class lasted 10 minutes. The main task was to return to the initial state of pulse and respiration, to relieve muscle tension.

The current control was performed three times during the study - at the end of each mesocycle (on November, on December, on February). The dynamics of physique indicators of adult women under the influence of a differentiated approach was studied. The program of aqua fitness classes was corrected according to the results of current control.

Anthropometric examination was performed by standard devices according to the known unified method: chest $(\mathrm{cm})$, shoulder $(\mathrm{cm})$, calf $(\mathrm{cm})$, thigh $(\mathrm{cm})$, waist $(\mathrm{cm})$, buttocks $(\mathrm{cm})$ and wrist $(\mathrm{cm})$ circumferences with measuring tape; body weight $(\mathrm{kg})$ was determined with medical scales. To determine the overweight the body mass index was calculated (Krutsevich, Vorobjov \& Bezverhnya, 2011).

Assessment of body shape harmony was performed by calculating the index of proportionality of circumferential sizes by dividing the value of body length $(\mathrm{cm})$ to the circumferential sizes of different body parts $(\mathrm{cm})$ and comparing actual and normative values (Krutsevich, Vorobjov, \& Bezverhnya, 2011). 
Pirohova, K., Myкytchyk, O., Afanasiev, S., Omelchenko, O., Sydorchuk, T., Stepanova, I., \& Kosheleva, O. (2021). Dynamics of Body Type Indicators of Adult Women Under the Influence of Aqua Fitness

Table 1. Dynamics of body composition of women from the first subgroup $(n=10)$

\begin{tabular}{|c|c|c|c|c|c|}
\hline \multirow[t]{2}{*}{ Indicators } & $\begin{array}{c}\text { Initial data } \\
\text { (September 2019) }\end{array}$ & $\begin{array}{c}\text { Current control } \\
\text { No. } 1 \text { (November } \\
\text { 2019) }\end{array}$ & $\begin{array}{c}\text { Current control } \\
\text { No. } 2 \text { (December } \\
\text { 2019) }\end{array}$ & $\begin{array}{c}\text { Current control } \\
\text { No. } 3 \text { (February } \\
2020)\end{array}$ & $\begin{array}{c}\text { Final data (March } \\
\text { 2020) }\end{array}$ \\
\hline & \multicolumn{5}{|c|}{$\mathrm{X} \pm \mathrm{s}$} \\
\hline \multirow{3}{*}{ Body weight, $\mathrm{kg}$} & \multirow{2}{*}{$62.75 \pm 5.45$} & \multirow{2}{*}{$62.40 \pm 5.30$} & $61.71 \pm 5.08$ & $60.80 \pm 4.71$ & \multirow{3}{*}{$\begin{array}{c}60.10 \pm 4.98^{*} \\
\mathrm{p}<0.05\end{array}$} \\
\hline & & & \multicolumn{2}{|c|}{$\mathrm{p}<0.01$} & \\
\hline & \multicolumn{4}{|c|}{$\mathrm{p}<0.05$} & \\
\hline \multirow{3}{*}{ Body mass index, $\mathrm{kg} / \mathrm{m}^{2}$} & \multirow{2}{*}{$22.75 \pm 2.39$} & \multirow{2}{*}{$22.62 \pm 2.36$} & $22.37 \pm 2.30$ & $22.04 \pm 2.17$ & \multirow{3}{*}{$\begin{array}{c}21.79 \pm 2.20^{*} \\
\mathrm{p}<0.05\end{array}$} \\
\hline & & & \multicolumn{2}{|c|}{$\mathrm{p}<0.01$} & \\
\hline & \multicolumn{4}{|c|}{$\mathrm{p}<0.05$} & \\
\hline Chest circumference, $\mathrm{cm}$ & $88.60 \pm 4.65$ & $88.50 \pm 4.50$ & $88.40 \pm 4.14$ & $88.30 \pm 4.19$ & $88.20 \pm 4.08$ \\
\hline \multirow{3}{*}{ Shoulder circumference, $\mathrm{cm}$} & \multirow{2}{*}{$28.50 \pm 3.37$} & $28.40 \pm 3.20$ & $27.80 \pm 2.90$ & \multirow{2}{*}{$26.80 \pm 2.90$} & \multirow{3}{*}{$\begin{array}{c}26.40 \pm 3.06^{*} \\
\mathrm{p}<0.05\end{array}$} \\
\hline & & \multicolumn{2}{|c|}{$\mathrm{p}<0.05$} & & \\
\hline & \multicolumn{4}{|c|}{$\mathrm{p}<0.01$} & \\
\hline \multirow{3}{*}{ Waist circumference, $\mathrm{cm}$} & \multirow{2}{*}{$68.80 \pm 6.27$} & $67.80 \pm 6.11$ & $66.60 \pm 5.74$ & \multirow{2}{*}{$65.40 \pm 5.34$} & \multirow{3}{*}{$\begin{array}{c}64.60 \pm 5.32^{*} \\
p<0.01\end{array}$} \\
\hline & & \multicolumn{2}{|c|}{$\mathrm{p}<0.05$} & & \\
\hline & \multicolumn{4}{|c|}{$\mathrm{p}<0,01$} & \\
\hline \multirow{2}{*}{ Thigh circumference, $\mathrm{cm}$} & $55.80 \pm 6.91$ & $55.20 \pm 6.73$ & $54.40 \pm 6.54$ & $53.70 \pm 6.30$ & \multirow{2}{*}{$\begin{array}{c}53.40 \pm 6.24^{*} \\
\mathrm{p}<0.01\end{array}$} \\
\hline & \multicolumn{4}{|c|}{$\mathrm{p}<0.05$} & \\
\hline Buttocks circumference, $\mathrm{cm}$ & $89.20 \pm 17.18$ & $88.60 \pm 17.12$ & $88.10 \pm 17.28$ & $87.20 \pm 16.88$ & $86.10 \pm 16.54$ \\
\hline Calf circumference, $\mathrm{cm}$ & $33.50 \pm 4.14$ & $33.40 \pm 4.27$ & $33.30 \pm 4.16$ & $32.80 \pm 4.29$ & $32.50 \pm 4.35$ \\
\hline \multirow{2}{*}{ Wrist circumference, $\mathrm{cm}$} & $16.00 \pm 0.82$ & $16.10 \pm 0.74$ & $16.20 \pm 0.79$ & $16.30 \pm 0.67$ & \multirow{2}{*}{$\begin{array}{c}16.40 \pm 0.70^{*} \\
\mathrm{p}<0.01\end{array}$} \\
\hline & \multicolumn{4}{|c|}{$\mathrm{p}<0.05$} & \\
\hline
\end{tabular}

* - statistically significant difference between the initial and final indicators.

Table 2. Dynamics of body composition of women from the second subgroup $(n=10)$

\begin{tabular}{|c|c|c|c|c|c|}
\hline Indicators & $\begin{array}{c}\text { Initial data } \\
\text { (September 2019) }\end{array}$ & $\begin{array}{c}\text { Current control } \\
\text { No. } 1 \text { (November } \\
2019 \text { ) }\end{array}$ & $\begin{array}{c}\text { Current control } \\
\text { No. } 2 \text { (December } \\
2019 \text { ) } \\
\end{array}$ & $\begin{array}{c}\text { Current control } \\
\text { No. } 3 \text { (February } \\
2020 \text { ) } \\
\end{array}$ & $\begin{array}{l}\text { Final data (March } \\
\text { 2020) }\end{array}$ \\
\hline & & & $\mathrm{X} \pm \mathrm{s}$ & & \\
\hline Body weight, kg & $63.50 \pm 7.56$ & $63.20 \pm 7.04$ & $62.80 \pm 7.37$ & $62.10 \pm 7.12$ & $61.60 \pm 7.34$ \\
\hline \multirow{2}{*}{ Body mass index, $\mathrm{kg} / \mathrm{m}^{2}$} & $25.38 \pm 1.52$ & $21.95 \pm 1.39$ & $21.81 \pm 1.30$ & $21.57 \pm 1.19$ & \multirow{2}{*}{$\begin{array}{c}21.38 \pm 1.00^{*} \\
p<0.01\end{array}$} \\
\hline & \multicolumn{4}{|c|}{$\mathrm{p}<0.05$} & \\
\hline Chest circumference, $\mathrm{cm}$ & $86.30 \pm 6.43$ & $86.20 \pm 6.36$ & $86.00 \pm 5.71$ & $85.90 \pm 5.62$ & $85.80 \pm 5.38$ \\
\hline \multirow{3}{*}{ Shoulder circumference, $\mathrm{cm}$} & \multirow{2}{*}{$29.80 \pm 2.85$} & $29.20 \pm 3.27$ & $28.20 \pm 2.94$ & \multirow{2}{*}{$27.50 \pm 2.99$} & \multirow{3}{*}{$\begin{array}{c}26.80 \pm 2.50^{*} \\
\mathrm{p}<0.01\end{array}$} \\
\hline & & $\mathrm{p}<$ & 0.05 & & \\
\hline & \multicolumn{4}{|c|}{$\mathrm{p}<0.01$} & \\
\hline Waist circumference, $\mathrm{cm}$ & $71.00 \pm 10.11$ & $70.10 \pm 9.67$ & $69.10 \pm 9.48$ & $68.20 \pm 8.16$ & $\begin{array}{c}66.90 \pm 8.22^{*} \\
p<0.05\end{array}$ \\
\hline \multirow{2}{*}{ Thigh circumference, $\mathrm{cm}$} & $61.00 \pm 9.41$ & $59.90 \pm 8.98$ & $59.10 \pm 8.46$ & $57.90 \pm 8.19$ & \multirow{2}{*}{$\begin{array}{c}56.90 \pm 7.45^{\star} \\
p<0.05\end{array}$} \\
\hline & \multicolumn{3}{|c|}{$\mathrm{p}<0.05$} & & \\
\hline \multirow{3}{*}{ Buttocks circumference, $\mathrm{cm}$} & $94.40 \pm 4.27$ & $93.60 \pm 4.07$ & $92.50 \pm 4.20$ & \multirow{2}{*}{$90.60 \pm 3.64$} & \multirow{3}{*}{$\begin{array}{c}90.80 \pm 3.68^{*} \\
\mathrm{p}<0.01\end{array}$} \\
\hline & & $\mathrm{p}<0.05$ & & & \\
\hline & \multicolumn{4}{|c|}{$\mathrm{p}<0,01$} & \\
\hline Calf circumference, $\mathrm{cm}$ & $34.50 \pm 8.47$ & $33.90 \pm 8.20$ & $33.80 \pm 7.76$ & $33.20 \pm 7.57$ & $\begin{array}{c}33.00 \pm 7.44^{*} \\
p<0.05\end{array}$ \\
\hline Wrist circumference, $\mathrm{cm}$ & $15.20 \pm 1.89$ & $15.30 \pm 1.89$ & $15.40 \pm 1.90$ & $15.50 \pm 1.38$ & $\begin{array}{c}15.86 \pm 1.07^{\star} \\
p<0.05\end{array}$ \\
\hline
\end{tabular}

* - statistically significant difference between the initial and final indicators. 
Table 3. Dynamics of body composition of women from the third subgroup ( $n=10)$

\begin{tabular}{|c|c|c|c|c|c|}
\hline \multirow[t]{2}{*}{ Indicators } & $\begin{array}{c}\text { Initial data } \\
\text { (September 2019) }\end{array}$ & $\begin{array}{c}\text { Current control } \\
\text { No. } 1 \text { (November } \\
2019 \text { ) } \\
\end{array}$ & $\begin{array}{c}\text { Current control } \\
\text { No. } 2 \text { (December } \\
2019) \\
\end{array}$ & $\begin{array}{c}\text { Current control } \\
\text { No. } 3 \text { (February } \\
2020) \\
\end{array}$ & $\begin{array}{c}\text { Final data (March } \\
\text { 2020) }\end{array}$ \\
\hline & \multicolumn{5}{|c|}{$\mathrm{X} \pm \mathrm{s}$} \\
\hline \multirow{2}{*}{ Body weight, $\mathrm{kg}$} & $93.50 \pm 14.39$ & $92.40 \pm 14.18$ & $90.40 \pm 13.95$ & $88.50 \pm 14.25$ & $87.30 \pm 13.82^{*}$ \\
\hline & \multicolumn{4}{|c|}{$\mathrm{p}<0.05$} & $\mathrm{p}<0.01$ \\
\hline \multirow{2}{*}{ Body mass index, $\mathrm{kg} / \mathrm{m}^{2}$} & $31.45 \pm 3.36$ & $31.08 \pm 3.29$ & $30.40 \pm 3.21$ & $29.74 \pm 3.29$ & $29.34 \pm 3.14^{*}$ \\
\hline & \multicolumn{4}{|c|}{$\mathrm{p}<0.05$} & $\mathrm{p}<0.01$ \\
\hline Chest circumference, $\mathrm{cm}$ & $106.50 \pm 13.50$ & $150.10 \pm 12.78$ & $130.50 \pm 12.38$ & $102.30 \pm 11.91$ & $\begin{array}{c}101.10 \pm 11.06^{*} \\
\mathrm{p}<0.01\end{array}$ \\
\hline \multirow{2}{*}{ Shoulder circumference, $\mathrm{cm}$} & $36.40 \pm 5.25$ & $35.60 \pm 4.97$ & $34.60 \pm 4.33$ & $33.40 \pm 3.53$ & \multirow{2}{*}{$\begin{array}{c}32.50 \pm 3.17^{\star} \\
p<0.01\end{array}$} \\
\hline & \multicolumn{4}{|c|}{$\mathrm{p}<0.05$} & \\
\hline \multirow{2}{*}{ Waist circumference, $\mathrm{cm}$} & $91.50 \pm 11.76$ & $90.50 \pm 11.54$ & $88.70 \pm 10.94$ & $87.80 \pm 10.28$ & \multirow{2}{*}{$\begin{array}{c}86.70 \pm 10.07^{\star} \\
p<0.01\end{array}$} \\
\hline & \multicolumn{4}{|c|}{$\mathrm{p}<0.05$} & \\
\hline \multirow{2}{*}{ Thigh circumference, $\mathrm{cm}$} & $68.40 \pm 9.32$ & $68.00 \pm 9.01$ & $66.50 \pm 8.67$ & $65.20 \pm 8.92$ & \multirow{2}{*}{$\begin{array}{c}63.60 \pm 8.35^{*} \\
p<0.01\end{array}$} \\
\hline & \multicolumn{4}{|c|}{$\mathrm{p}<0.05$} & \\
\hline Buttocks circumference, $\mathrm{cm}$ & $113.70 \pm 14.35$ & $112.60 \pm 14.09$ & $111.00 \pm 13.70$ & $109.50 \pm 13.26$ & $\begin{array}{c}107.40 \pm 13.01^{*} \\
\mathrm{p}<0.01\end{array}$ \\
\hline Calf circumference, $\mathrm{cm}$ & $41.90 \pm 8.02$ & $41.80 \pm 7.80$ & $41.30 \pm 7.24$ & $40.90 \pm 7,16$ & $40.20 \pm 7.24$ \\
\hline \multirow{2}{*}{ Wrist circumference, $\mathrm{cm}$} & $19.80 \pm 1.69$ & $19.60 \pm 1.84$ & $19.50 \pm 1.72$ & $19.10 \pm 1.37$ & \multirow{2}{*}{$\begin{array}{c}18.90 \pm 1.45^{*} \\
p<0.01\end{array}$} \\
\hline & \multicolumn{4}{|c|}{$\mathrm{p}<0.05$} & \\
\hline
\end{tabular}

* - statistically significant difference between the initial and final indicators.

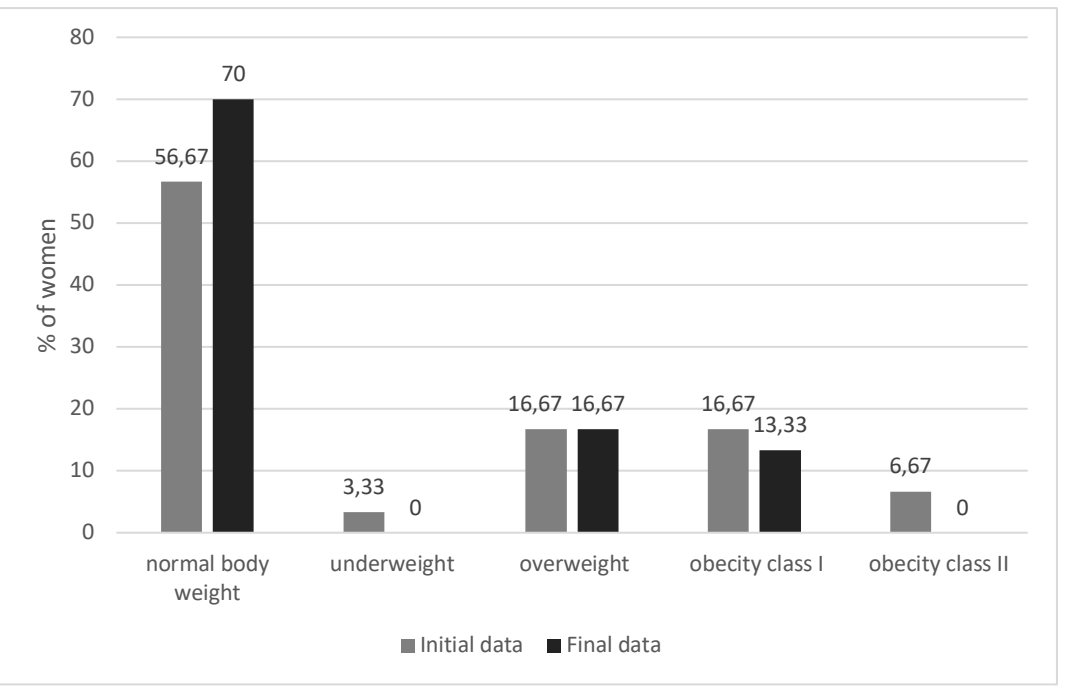

Fig. 1. Dynamics of changes in body mass index of adult women, $\%$

\section{Statistical analysis}

Study results were processed using the "Data Analysis" package of Microsoft Excel spreadsheets. Descriptive statistics (mean and standard deviation) were determined. The reliability of the differences was estimated by the Wilcoxon signed-rank test; the withdrawal was considered to be reliable at $\mathrm{p}<$ 0.05-0.01 (Byshevets et al., 2019).

\section{Results}

In order to determine the effectiveness of a differentiated approach in aqua fitness classes with women of mature age, we studied the dynamics of their body type indicators.
Analysis of the dynamics of body composition of women from the first subgroup of normosthenic type (Table 1) during the current control no 2 showed a statistically significant decrease in shoulder circumference and waist $(\mathrm{p}<$ $0.05)$. Current control no 3 recorded a statistically significant improvement in body weight, body mass index $(\mathrm{p}<0,01)$, shoulder circumference, waist, thigh and wrist $(\mathrm{p}<0.05)$. At the end of the study, statistically significant improvement ( $\mathrm{p}$ $<0.05-0.01$ ) was determined in body mass index, shoulder, thigh, waist and wrist circumferences within the age norm.

Women from the second subgroup (Table 2) mostly needed to tone their muscle tissue. Statistically significant changes in the circumferential parameters of the shoulder 
$(\mathrm{p}<0.05)$ and buttocks $(\mathrm{p}<0.4)$ were recorded at the stage of the second current control. Current control no 3 determined an increase in muscle tone of shoulder $(\mathrm{p}<0.01)$, thigh ( $\mathrm{p}<0.05)$, buttocks $(\mathrm{p}<0.01)$ circumferences. At the end of the study we recorded a statistically significant improvement in body mass index $(\mathrm{p}<0.01)$, shoulder $(\mathrm{p}<0.01)$, waist $(\mathrm{p}<0.05)$, thigh $(\mathrm{p}<0.05)$, buttocks $(\mathrm{p}<0.01)$, calf $(\mathrm{p}<0.05)$ and wrist $(\mathrm{p}<0.05)$ circumferences in women of this subgroup.

Women of the third subgroup required weight loss and circumference parameters (Table 3 ). Current control no 1 and 2 recorded statistically insignificant changes in women 's circumference parameters. Current control no 3 revealed a statistically significant decrease in body weight $(\mathrm{p}<0.05)$, body mass index, shoulder, waist, thigh, wrist $(\mathrm{p}<0.05)$ circumferences. At the end of the study, all body parameters of women (except for curl circumference) had a statistically significant improvement $(\mathrm{p}<0.01)$.

In order to assess the effectiveness of the implemented differentiated approach in aqua fitness with women of the first period of adulthood, the dynamics of changes in their body mass index was estimated. At the end of the study, there were no women with obesity class II and underweight. The number of women with obesity class I decreased by $3.33 \%$. The number of women with normal body weight increased by $13.37 \%$.

\section{Discussion}

Researchers have shown that most women of the first period of adulthood choose aqua fitness to increase their level of motor activity and improve body composition (Rýzková et al., 2018; Shalaeva et al., 2018; Vysotskaya et al., 2020). This causes a necessity of the development of new modern programs of wellness classes for women, taking into account the indicators of their physique (Dorofeeva et al., 2018; Byshevets et al., 2019; Leiros-Rodriguez et al., 2019; Andrieieva et al., 2019; Goncharova et al., 2020).

We have developed and implemented a differentiated approach to aqua fitness classes with women of the first mature age, depending on their body type. This approach also took into account the compositional constitution of the body. The intensity of the load, the pace and time of exercise and combination performance, the number of repetitions, the alternation of working positions and rest intervals depended on the body type of women.

The results of the study show that at the end of the study, the majority of women had a normal body weight. Body mass index in $100 \%$ of women of the first and second subgroups was within normal limits. In the third subgroup, 10\% of women had this indicator within normal limits, $50 \%$ had overweight, and $40 \%$ had obesity class I.

We have confirmed scientists' data (Shalaeva et al., 2018; Andrieieva et al., 2019; Vysotskaya et al., 2020) that aqua fitness has a positive effect on women's physique.

Knowledge about the impact of fitness on the correction of physical condition of overweight women (Borovik, 2013; Andrieieva et al., 2019; Goncharova et al., 2020) were further developed. Information about methods of physical training with use physical activity of various types based on body composition (Shutova \& Vysotskaya, 2019), some issues of complex aqua fitness classes to improve women's physical fitness (Shalaeva, et al., 2018; Podrihalo et al., 2020) were continued.

Scientific data (Hakman, Duditskaya, Slobozhaninov \& Kovtun, 2020; Kostrzewa-Nowak, Nowakowska, Zwierko, Rybak, \& Nowak, 2020) have confirmed that aqua fitness classes are the most effective for improving the physical state of adult women.

Information about the features of building a comprehensive program of wellness training for adult women (Artemyeva, Latvinska \& Moshenska, 2020; Prylutska et al., 2019), the positive impact of aqua fitness on adult women's body (Kashuba et al., 2019; Sarah, Derek \& Katie, 2019; Williams, Barreria \& Tseh, 2020) was extended and supplemented.

\section{Conclusions}

The implementation of a differentiated approach to aqua fitness with women of the first period of adulthood has significantly adjusted their body proportions. To the end of the study, there were no women with obesity class II and underweight. The number of women with obesity class I decreased by $3.33 \%$. The number of women with normal body weight increased by $13.37 \%$.

According to women's body type we determined statistically significant improvements of their anthropometric parameters. Women with normosthenic body type had statistically significant improvement in body mass index, shoulder, thigh, waist and wrist circumferences within the age norm. A statistically significant improvement in body mass index, shoulder, waist, thigh, buttocks, calf and wrist circumferences was recorded in women of asthenic body type. Women with hypersthenic body type had statistically significant improvement of all body parameters except for curl circumference.

This indicates the effectiveness of the implemented differentiated approach in aqua fitness with women of these subgroups and allows recommending it for further implementation.

\section{Conflict of interest}

The authors declare that there are no conflicts of interest.

\section{References}

Leiros-Rodriguez, R., Romo-Perez, V., Perez-Ribao, I., \& Garcia-Soidan, J.L. (2019). A comparison of three physical activity programs for health and fitness tested with older women: Benefits of aerobic activity, aqua fitness, and strength training. Journal of Women \& Aging, 31(5), 419461. https://doi.org/10.1080/08952841.2018.1510242

Dorofeeva, O.E., Yarimbash, K.S., \& Zavatska, L.A. (2018). The effect of aqua aerobics on women's somatic health. Psychological and pedagogical bases of humanization of educational process in school and high school, 1(19), 169175. (in Ukrainian)

Prylutska, T., Khabinets, T., Lazko, O., Sobotyuk, S.Y., Bosakevych, M., \& Ivchenko, V. (2019). Characteristics of physical fitness of mature women engaged in slide aerobics. Youth Scientific Bulletin of the Lesia Ukrainka East European National University, 33, 49-55. (in Ukrainian)

Tomilina, J.I. (2016). Features of the physical condition of women of the first period of adulthood who practice 
Pilates. Young sports science of Ukraine, 4, 153-157. (in Ukrainian)

Anders, K., Bedorta, D. \& Brennan, D. (1992). Aquajogger: The ideal no impact exercises for all ages and levels of fitness. Sport science int'l Eugene, Oregon, 2-3.

Goncharova, N., Kashuba, V., Tkachova, A., Khabinets, T., Kostiuchenko, O., \& Pymonenko, M. (2020). Correction of Postural Disorders of Mature Age Women in the Process of Aqua Fitness Taking Into Account the Body Type. Teoriâ ta Metodika Fizičnogo Vihovannâ, 20(3), 127136. https://doi.org/10.17309/tmfv.2020.3.01

Rýzková, E., Labudov, J., Grznár, L., \& Šmída, M. (2018). Effects of aquafitness with high intensity interval training on physical fitness. Journal of Physical Education and Sport, 18(1), 373-381.

Shalaeva, I.Yu., Sazonova, I.M., \& Krokhina, T.A. (2018). The contents of the comprehensive aqua fitness classes to improve physical preparation of middle-aged women. Physical education and sports training, 4(26), 29-36. https://readera.org/140238537

Andrieieva, O., Hakman, A., Kashuba, V., Vasylenko, M., Patsaliuk, K., Koshura, A. \& Istyniuk, I. (2019). Effects of physical activity on aging processes in elderly persons. Journal of Physical Education and Sport, 19(s4), 1308-1314. https://doi.org/10.7752/jpes.2019.s4190

Vysotskaya, T., Shutova, T., \& Golubnichy, S. (2020). The effective means of aquafitness in correction of mature women's functional state. Journal of Human Sport and Exercise, 15(2proc), 189-199.

https://doi.org/10.14198/jhse.2020.15.proc2.09

Martyniuk, O.V. (2016). Functional condition of women of the first period of adulthood in the process of health fitness. Youth Scientific Bulletin of the Lesia Ukrainka East European National University. Physical education and sports, 22, 31-36. (in Ukrainian)

Tkachuk, V.P., Soverda, I.U., Stepanyuk, S.I. \& Kozibroda, L.V. (2019). Promoting the health of mature women through wellness technology. Bulletin of the Precarpathian University. Series: Physical culture, 32, 129-134. (in Ukrainian)

Belyak, Yu., Hrybovska, I., Muzyka, F., Ivanochko, V., \& Chekhovska, L. (2018). Theoretical and methodical bases of health fitness: navch. posib. Lviv: LDUFK. (in Ukrainian)

Kanishcheva, O.P. (2011). Differentiated approach to physical education of students with low adaptive capacity of the organism: abstract of cand. diss. Kharkiv: KhDAFK. (in Ukrainian)

Dargatz, T., \& Röwekam, A. (2017). Aqua-Fitness: AquaAerobic, Aqua-Power, Aqua-Jogging, Wassergymnastik. Hungary, 134.

Krutsevich, T., \& Marchenko, O. (2020). Conceptual approaches in researches of gender differentiation in physical education. Theory and methods of physical education and sports, 2, 85-94. (in Ukrainian)

Borovik, O. (2013). Differentiated approach in the process of physical culture and health-improving classes for women taking into account hereditary factors. Theory and methods of physical education and sports, 2, 59-63. (in Ukrainian)

Sitovsky, A.M. (2008). Differentiated approach in physical education of adolescents with different rates of biological development (on the example of 7 th grade students): abstract of cand. diss. Lviv: LDUFK. (in Ukrainian)

Ryabchenko, V.G. (2011). Differentiation of physical activity in girls 7-8 years with different physique at the initial stage of physical culture and health classes. Scientific journal, 16, 284-289. (in Ukrainian)

Trotsenko, T.U., \& Pivovarov, A.A. (2018). Prospects for the development of aqua fitness in physical education of primary school children. Young Scientist, 4.2(56.2), 199203. (in Ukrainian)

Foulis, S. A., Hughes, J. M., Walker, L. A., Guerriere, K. I., Taylor, K. M., Proctor, S. P., \& Friedl, K. E. (2021). Body mass does not reflect the body composition changes in response to similar physical training in young women and men. International Journal of Obesity, 45(3), 659-665. https://doi.org/10.1038/s41366-020-00730-0

Krutsevich, T.Yu., Vorobjov, M.I., \& Bezverhnya, G.V. (2011). Control in physical education of children, adolescents and youth. Kyiv: Olympic Literature. (in Ukrainian)

Byshevets, N., Denysova, L., Shynkaruk, O., Serhiyenko, K., Usychenko, V., Stepanenko O., \& Syvash I. (2019). Using the methods of mathematical statistics in sports and educational research of masters in physical education and sport. Journal of Physical Education and Sport, 19(3), 1030-1034.

Shutova, T., \& Vysotskaya, T. (2019). Development of methods of population's physical training by using various types of fitness based on body composition's accounting. Journal of Human Sport and Exercise, 14(Proc4), 877-884. https://doi.org/10.14198/jhse.2019.14.proc4.50

Podrihalo, O., Savina, S., Podrigalo, L., Iermakov, S., Jagiełł, W., Rydzik, Ł., \& Błach, W. (2020). Influence of Health Related Fitness on the Morphofunctional Condition of Second Mature Aged Women. International Journal of Environmental Research and Public Health, 17, 8465. https://doi.org/10.3390/ijerph17228465

Hakman, A.V., Duditskaya, S.P., Slobozhaninov, A.A., \& Kovtun, O.A. (2020). Health effects of aqua fitness on the body of women of the first mature age. Scientific journal of NPU named after M.P. Drahomanov, 7(127), 33-37. https://doi.org/10.31392/npu-nc.series15.2020.7(127).06 (in Ukrainian)

Kostrzewa-Nowak, D., Nowakowska, A., Zwierko, T., Rybak, M., \& Nowak, R. (2020). The Influence of a Health-Related Fitness Training Program on Motor Performance as Well as Hematological and Biochemical Parameters. International Journal of Environmental Research and Public Health, 17, 578. https://doi.org/10.3390/ijerph17020578

Artemyeva, G., Latvinska, I., \& Moshenska, T. (2020). Construction of a comprehensive health training program for women of the first period of adulthood. Slobozhanskyi herald of science and sport, 8(6), 107-120.

Kashuba, V., Andrieieva, O., Goncharova, N., Kyrychenko, V., Karp, I., Lopatskyi, S., \& Kolos, M.( 2019). Physical activity for prevention and correction of postural abnormalities in young women. Journal of Physical Education and Sport, 19(2), 500-506.

Sarah, J.C., Derek, A.C., \& Katie, M.H. (2019). Multiple Fitness Improvements Found after 6-Months of High Intensity Functional Training. Sports, 7(9), 203. https://doi.org/10.3390/sports7090203

Williams, R.E., Barreria, T.V., \& Tseh, W. (2020). Fitnessrelated benefits: land-based versus aqua-base. Journal of Sports Medicine and Physical Fitness, 60(1), 26-31. https://doi.org/10.23736/S0022-4707.19.09675-0 


\title{
ДИНАМІКА ПОКАЗНИКІВ ТІЛОБУДОВИ ЖІНОК ПЕРШОГО ПЕРІОДУ ЗРІЛОГО ВІКУ ПІД ВПЛИВОМ ЗАНЯТЬ АКВАФІТНЕСОМ
}

\author{
Карина Пірогова ${ }^{1 \mathrm{ABCD}}$, Ольга Микитчик ${ }^{1 \mathrm{ABCD}}$, Сергій Афанасьєв ${ }^{1 \mathrm{ABCD}}$, Олена \\ Омельченко $^{1 \mathrm{ABCD}}$, Тетяна Сидорчук ${ }^{1 \mathrm{ABCD}}$, Iрина Степанова $^{1 \mathrm{ABCD}}$, Олена Кошелева ${ }^{1 \mathrm{ABCD}}$ \\ ${ }^{1}$ Придніпровська державна академія фізичної культури і спорту \\ Авторський вклад: А - дизайн дослідження; В - збір даних; C - статаналіз; D - підготовка рукопису; Е - збір коштів \\ Реферат. Стаття: 7 с., 3 табл., 1 рис., 31 джерело.
}

У статті представлені зміни показників тілобудови жінок першого періоду зрілого віку під впливом занять аквафітнесом.

Мета дослідження - визначити ефективність диференційованого підходу до занять аквафітнесом з жінками першого періоду зрілого віку.

Матеріал і методи. У дослідженні взяли участь 30 жінок першого періоду зрілого віку, середній вік яких склав $30,57 \pm 3,63$ років. Дослідження проводилось протягом 20192020 років. Антропометричні вимірювання визначали довжину тіла, масу тіла, окружність грудної клітки, обхват плеча, гомілки, стегна, талії, сідниць та зап’ястку. Для визначення наявності надлишкової ваги розрахувалися індекс маси тіла. Вимірювання проводились наприкінці кожного мезоциклу оздоровчого тренування. Статистичний аналіз охоплював визначення середнього, середньоквадратичного відхилення, достовірності відмінностей (t-критерій Вілкоксона).
Результати. Ефективність диференційованого підходу до занять аквафітнесом доведена покращенням показників тілобудови жінок. Наприкінці дослідження серед загальної кількості обстежених жінок не було виявлено жінок з ожирінням II ступеня та з дефіцитом маси тіла. На 3,33\% зменшилася кількість жінок з ожирінням I ступеня. На 13,37\% зросла кількість жінок з нормальною масою тіла. Також визначено статистично значуще поліпшення антропометричних параметрів жінок з різними типами тілобудови.

Висновки. Впровадження диференційованого підходу до занять аквафітнесом з жінками першого періоду зрілого віку дозволило значно скорегувати їх пропорції тіла. Це дозволяє рекомендувати використання диференційованого підходу залежно від типу тілобудови у оздоровчих заняттях аквафітнесом.

Ключові слова: аквафітнес, тілобудова, диференційований підхід, корекція пропорцій тіла, оздоровчі заняття.

\section{Information about the authors:}

Pirohova K.: karina.swim@ukr.net; https://orcid.org/0000-0001-8613-2853; PhD student, Prydniprovsk State Academy of Physical Culture and Sport, Naberezhna Peremohy St, 10, Dnipro, 49094, Ukraine.

Мукуtchyk O.: molga.0604@gmail.com; https://orcid.org/0000-0002-0047-4359; Department of Water Sport, Prydniprovsk State Academy of Physical Culture and Sport, Naberezhna Peremohy St, 10, Dnipro, 49094, Ukraine.

Afanasiev S.: admin_infiz@ukr.net; https://orcid.org/0000-0001-7739-3461; First Vice-rector for Scientific and Pedagogical Work, Prydniprovsk State Academy of Physical Culture and Sport, Naberezhna Peremohy St, 10, Dnipro, 49094, Ukraine.

Omelchenko O.: ollenka7777@gmail.com; https://orcid.org/0000-0002-8862-8075; Department of Water Sport, Prydniprovsk State Academy of Physical Culture and Sport, Naberezhna Peremohy St, 10, Dnipro, 49094, Ukraine.

Sydorchuk T.: sydorchuk1704@gmail.com; https://orcid.org/0000-0001-7129-1616; Department of Theory and Methods of Physical Education, Prydniprovsk State Academy of Physical Culture and Sport, Naberezhna Peremohy St, 10, Dnipro, 49094, Ukraine.

Stepanova I.: siv260180@gmail.com; https://orcid.org/0000-0002-5431-8052; Department of Theory and Methods of Physical Education, Prydniprovsk State Academy of Physical Culture and Sport, Naberezhna Peremohy St, 10, Dnipro, 49094, Ukraine.

Kosheleva O.: koshelevaea@gmail.com; https://orcid.org/0000-0002-9085-6800; Department of Theory and Methods of Physical Education, Prydniprovsk State Academy of Physical Culture and Sport, Naberezhna Peremohy St, 10, Dnipro, 49094, Ukraine.

Cite this article as: Pirohova, K., Мукуtchyk, O., Afanasiev, S., Omelchenko, O., Sydorchuk, T., Stepanova, I., \& Kosheleva, O. (2021). Dynamics of Body Type Indicators of Adult Women Under the Influence of Aqua Fitness. Teoriâ ta Metodika Fizičnogo Vihovannâ, 21(2), 129-135. https://doi.org/10.17309/tmfv.2021.2.05

Received: 24.02.2021. Accepted: 18.05.2021. Published: 25.06.2021

This work is licensed under a Creative Commons Attribution 4.0 International License (http://creativecommons.org/licenses/by/4.0). 